10. Shwachman, H.: Changing concepts of cystic fibrosis. Hosp. Pract., January: 143 (1974).

11. Exax 45060, Kimble, Owens-Illinois, Inc., Toledo, Ohio.

12. Model 96CV-Clear, Linbro Chemical Co., Inc., New Haven, Conn.

13. Gilson Medical Electronics. Middleton, Wisc.

14. Aquarium Systems, Inc., Eastlake, Ohio.

15. The assistance of Alice Pigg, Marianne Karn, and Joann Stafford in collecting the specimens is gratefully acknowledged. We are indebted to Dr. Frank P Conte of Oregon State University for the data of Table 2.
16. Drs. Hodes and Merritt were supported in part by grants from the J. W. Riley Memorial Association and Public Health Service Research Grants AM 13428 and GM 21054 .

17. John Thomas was supported by National Institutes of Health Training Grant GM 1056.

18. Requests for reprints should be addressed to: M. E. Hodes, M.D., Ph.D. Department of Medical Genetics, Indiana University School of Medicine, 1100 W. Michigan St., Indianapolis, Ind. 46202 (USA).

19. Accepted for publication May 9, 1975.

\title{
Glucose Production in the Newborn Dog. I. Effects of Glucagon in Vivo
}

\author{
PETER A. J. ADAM, GARY GLAZER, AND FREDERICK ROGOFF \\ Department of Pediatrics, Case Western Reserve University School of Medicine at Cleveland Metropolitan General Hospital, \\ Cleveland, Ohio (USA)
}

\section{Extract}

Systemic glucose production rates were evaluated $4 \mathrm{hr}$ after feeding in 14 newborn beagle dogs at ages between 1 and 5 days. After a prime injection of radioisotopic tracers, glucose production was determined during infusion of intermixed tracer $\left[2-{ }^{3} \mathrm{H}\right]$ glucose and $\left[1-{ }^{14} \mathrm{C}\right]$ glucose at a constant rate. Seven of the newborn dogs served as controls throughout the 3 -hr period of infusion, while seven of their littermates, infused simultaneously, received glucagon at a constant rate of $3.3 \mu \mathrm{g} / \mathrm{min}$ between 90 and $180 \mathrm{~min}$ of study. In control dogs, mean glucose production, determined by dilution of $\left[2-{ }^{3} \mathrm{H}\right]$ glucose, was $55 \pm 3 \mu \mathrm{mol} / \mathrm{min} \cdot \mathrm{kg}$ body weight. During the control period, their littermates produced glucose at a similar rate; however, glucagon infusion raised glucose production to $81 \pm 4$ $\mu \mathrm{mol} / \mathrm{min} \cdot \mathbf{k g}$.

The average glucose production rate estimated with $\left[1-{ }^{14} \mathrm{C}\right]$ glucose was $88 \%$ of that with the ${ }^{3} \mathrm{H}$ tracer during the initial control period and $77 \%$ during the glucagon infusion. In order to confirm that this discrepancy reflected the recycling of ${ }^{14} \mathrm{C}$ and the early development of gluconeogenesis, an additional 14 newborn dogs were infused with potential substrates for $\left[{ }^{14} \mathrm{C}\right]$ glucose. In separate studies, $\left[U-{ }^{14} \mathrm{C}\right]$ lactate, $\left[3-{ }^{14} \mathrm{C}\right]$ lactate, $\left[U-{ }^{14} \mathrm{C}\right]$ alanine, and $\left[6-{ }^{14} \mathrm{C}\right]-$ glucose were incorporated into glucose and $\left[1-{ }^{14} \mathrm{C}\right]$ glucose. Quantification of gluconeogenesis by simultaneous infusion of $\left[6-{ }^{3} \mathrm{H}\right] \mathrm{glu}-$ cose and $\left[3-{ }^{14} \mathrm{C}\right]$ lactate in a 5-day-old dog demonstrated that $25 \%$ of the glucose produced originated from lactate, whereas $10 \%$ was incorporated into carbon 1 . Thus, systemic glucose production was established rapidly in newborn dogs and responded to stimulation with glucagon. A significant proportion of the glucose originated from recycling via the gluconeogenic pathway.

\section{Speculation}

Even in well nourished newborn mammals, recycling of glucose is important in maintaining homeostasis during the postabsorptive period. Based on comparisons between dogs infused with [3$\left.{ }^{14} \mathrm{C}\right]$ lactate or $\left[6-{ }^{-14} \mathrm{C}\right]$ glucose, $25 \%$ or more of hepatic glucose production may originate from glucose recycled through lactate and pyruvate. Presumably most of the rest is derived from hepatic glycogen stored in utero.
Shortly after separation from the maternal glucose supply, a newborn animal must establish hepatic and perhaps renal glucose production in order to maintain the blood glucose at physiological levels (1). In the fasting newborn infant or mammal, plasma insulin remains at relatively low levels, whereas plasma glucagon levels rise $(8,13)$. Since the normal newborn infant or mammal is able to stabilize the blood glucose concentration shortly after birth, normoglycemia is attributed to stimulation of hepatic glucose production by a preponderance of glucagon over insulin effect.

Hepatic glucose production has been quantified previously in newborn dogs utilizing uniformly labeled $\left[{ }^{14} \mathrm{C}\right]$ glucose (11) or $\left[2{ }^{3} \mathrm{H}\right]$ glucose as a tracer $(15)$. In studies of adult dogs, however, uniformly labeled glucose has underestimated systemic glucose production rates (10), particularly in the presence of hormonal stimulation with methylprednisolone. The presumed reason for this reduced estimate is recycling of ${ }^{14} \mathrm{C}$ in glucose.

Such recycling in the newborn would depend on development of enzymatic activities associated with gluconeogenesis. In recent studies hepatic fructose diphosphatase, phosphoenolpyruvate carboxykinase, and mitochondrial pyruvate carboxylase activities rise to physiological levels within the first day after birth $(4,5)$. Thus, the potential for recycling exists, could cause underestimation of neonatal glucose production, and may contribute substantially to glucose homeostasis.

The potential for hormonal control of hepatic glucose production by insulin, pancreatic glucagon, and splanchnic neural norepinephrine has been evaluated in vivo and in vitro in newborn dogs. From $4.5 \mathrm{hr}$ to 55 days of age, infusion of glucose alone or with physiological quantities of insulin suppresses glucose production in young dogs ineffectively compared with adults, indicating "resistance" to insulin action (15). Pharmacological quantities of glucagon in vivo raise systemic glucose production 36\% during [U${ }^{14} \mathrm{C}$ ]glucose infusion (11), whereas norepinephrine, $10^{-6} \mathrm{M}$, in vitro, raises glucose production by the isolated perfused liver $71 \%$ above control levels $(4,5)$. The response to glucagon $10^{-6} \mathrm{M}$ in vitro is of a similar magnitude (4).

The present study was done to quantify hepatic glucose production, gluconeogenesis, and recycling of glucose in the newborn dog. In addition the effects of pharmacological doses of glucagon were 
re-examined in the context of a methodology which estimates minimum values for recycling of carbon.

\section{METHODS AND MATERIALS}

\section{MATERIALS}

Isotopic tracers used in the studies were purchased from New England Nuclear (16); enzymes used in the assays were purchased from Sigma (17); glucagon and insulin were purchased from Eli Lilly (18).

\section{SURGICAL PROCEDURES}

Pregnant beagles were maintained in kennels and fed a standard diet for 1 week before delivery. Newborn puppies were fed ad libitum by their mothers until $4 \mathrm{hr}$ before the study. Two hours before infusion with radioisotopes the newborn dogs were restrained without general anesthesia; then indwelling polyethylene catheters were inserted under local anesthesia in one femoral vein for infusion, and in the right external jugular vein to the level of the right heart for sampling. These catheters were kept patent with a $100 \mu \mathrm{U} / \mathrm{ml}$ heparin-saline solution. The body temperature of newborn dogs was monitored rectally and maintained at $36-38^{\circ}$ with a radiant lamp. During each study water was offered and ingested from soft-tipped syringes. Under these conditions the puppies remained at rest and appeared to be healthy.

\section{STUDY PROTOCOLS}

Estimation of Systemic Glucose Production with $\left[2-{ }^{3} \mathrm{H}\right]$ Glucose $\left(G 2^{3} \mathrm{H}\right)$ and $\left[1-{ }^{14} \mathrm{C}\right]$ Glucose $\left(G l^{14} \mathrm{C}\right)$. Fourteen newborn dogs, ages 1,3 , and 5 days of age were studied by infusion of intermixed $\mathrm{G} 2^{3} \mathrm{H}$ and $\mathrm{G} 1{ }^{14} \mathrm{C}$. A solution of tracers in isotonic saline containing $11.54 \mu \mathrm{Ci} \mathrm{G} 2{ }^{3} \mathrm{H}$ and $5.77 \mu \mathrm{Ci} \mathrm{G} 1{ }^{14} \mathrm{C}$ was injected rapidly and followed with a constant rate infusion of $\mathrm{G} 2{ }^{3} \mathrm{H}(0.13 \mu \mathrm{Ci} / \mathrm{min})$ and $\mathrm{G} 1^{14} \mathrm{C}(0.064 \mu \mathrm{Ci} / \mathrm{min})$ for $3 \mathrm{hr}$. Seven of the newborn dogs served as controls throughout the 3-hr period of study, whereas seven of their littermates, infused simultaneously, received glucagon at a constant rate of $3.3 \mu \mathrm{g} / \mathrm{min}$ between 90 and $180 \mathrm{~min}$ of the study period. Half-milliliter blood samples were obtained during fasting and at $30,60,75,90,120,150,165$, and $180 \mathrm{~min}$ of the study. The continuous infusion of tracers in isotonic saline solution replaced the blood removed for study. Samples were cooled to $0^{\circ}$ on ice, plasma separated from red blood cells by centrifugation, and plasma stored at $-20^{\circ}$ until assay. The plasma samples were assayed for glucose, $\mathrm{G} 2{ }^{3} \mathrm{H}$ specific activity, and $\mathrm{G} 1{ }^{14} \mathrm{C}$ specific activity as indicated in the analyses.

Incorporation of Substrates into Glucose and $\left[1-{ }^{14} \mathrm{C}\right]$ Glucose. An additional 14 newborn dogs were studied between $4 \mathrm{hr}$ and 8 days of age with constant rate infusions of potential substrates for $\left[1-{ }^{14} \mathrm{C}\right]$ glucose. The dose of substrates was standardized so that all puppies received an $11.54 \mu \mathrm{Ci}$ prime and $0.13 \mu \mathrm{Ci} / \mathrm{min}$ infusions of ${ }^{14} \mathrm{C}$-labeled tracer substrates for a period of $180 \mathrm{~min}$. Four of these newborn dogs, ages $4 \mathrm{hr}-6$ days, received $\left[U-{ }^{14} \mathrm{C}\right]$ lactate $\left(\mathrm{L} U{ }^{14} \mathrm{C}\right)$; three, ages $1-5$ days, received $\left[3-{ }^{14} \mathrm{C}\right]$ lactate $\left(\mathrm{L} 3{ }^{14} \mathrm{C}\right)$; and one, 8 days old, received $\left[U-{ }^{14} \mathrm{C}\right]$ alanine $\left(\mathrm{A} \mid U^{14} \mathrm{C}\right)$. Six of the dogs, ages $4 \mathrm{hr}-8$ days, received $\left[6-{ }^{14} \mathrm{C}\right]$ glucose $\left(\mathrm{G} 6{ }^{14} \mathrm{C}\right)$ in order to demonstrate directly the recycling of C-6 into the $\mathrm{C}_{1}$ position of glucose.

Five of the dogs served as controls throughout the study period; four received a single dose of insulin $(0.1 \mathrm{U} / \mathrm{kg}$ iv) at $90 \mathrm{~min}$ of the study; and five received glucagon at a lower dose $(0.17 \mu \mathrm{g} / \mathrm{min}$ after $90 \mathrm{~min}$ ) than the previous newborn dogs. Plasma samples were obtained from these dogs for the assay of $\left[1-{ }^{14} \mathrm{C}\right]$ glucose at $15,30,60,90,105,120,150$, and $180 \mathrm{~min}$. Insulin or glucagon at the doses used did not affect incorporation of label, so that the results have been pooled and normalized for body weight.

Quantification of Gluconeogenesis. One 5-day-old dog infused with $\left[3-{ }^{14} \mathrm{C}\right]$ lactate was infused with $\left[6-{ }^{3} \mathrm{H}\right]$ glucose at the same dosage level. In this dog, plasma $\left[{ }^{14} \mathrm{C}\right]$ glucose was separated from $\left[{ }^{14} \mathrm{C}\right]$ lactate chromatographically, and the specific activities of $\left[{ }^{14} \mathrm{C}\right]$ lactate, $\left[{ }^{14} \mathrm{C}\right]$ glucose, $\left[1-{ }^{14} \mathrm{C}\right]$ glucose, and $\left[6-{ }^{3} \mathrm{H}\right]$ glucose were determined to evaluate the contribution of gluconeogenesis to the glucose pool.

\section{ANALYSES}

Plasma samples were precipitated with $10 \%$ perchloric acid and neutralized with $\mathrm{K}_{2} \mathrm{CO}_{3}$. Glucose was determined spectrophotometrically by coupling hexokinase and glucose 6-phosphate dehydrogenase activities (2): $\left|1-{ }^{14} \mathrm{C}\right|$ glucose radioactivity was assayed in an aliquot using 6-phosphogluconate dehydrogenase to cleave $\mathrm{CO}_{2}$ from $\mathrm{C}_{1}$ of glucose as reported previously (2). Before assessment of $\left[{ }^{3} \mathrm{H}\right]$ glucose by column chromatography and liquid scintillation, supernatants from precipitated plasma specimens were evaporated to dryness and reconstituted with fresh unlabeled water. The evaporation served to remove tritiated water from plasma filtrates so that label remained only in glucose and its metabolic derivatives. As reported previously, negligible quantities of tritium from $\left[2-{ }^{3} \mathrm{H}\right]$ glucose are incorporated into glycerol or lactate in vivo during studies of newborn, young, and adult dogs $(10,15)$. In contrast, the quantity of ${ }^{3} \mathrm{H}$ in plasma organic acid during the infusion of $\left[6{ }^{3} \mathrm{H}\right]$ glucose was approximately $50 \%$ of that in glucose at a steady state. Under these conditions, radioactivity in glucose was separated from that in lactate by anion exchange as reported previously (2); plasma lactate was assayed with lactate dehydrogenase (2).

Radioactivity in ${ }^{14} \mathrm{C}$ and ${ }^{3} \mathrm{H}$ were determined by liquid scintillation with an external standard. All counts were corrected for background, the appropriate blank, and quenching. Intermixed isotopes, recovered in the dried samples and from the anion exchange columns, were determined by subtraction after the appropriate corrections documented above. Radioactivity in all samples was expressed as the disintegration rate (disintegrations per $\min )$.

\section{CALCULATIONS}

Glucose Production Rate. Glucose production rate (Fig. 1, Table 1) was calculated assuming a steady state. As indicated in the results (Fig. 1), a virtual steady state was established after 30 min in the control studies. During infusions with glucagon, a steady state was not established until $60 \mathrm{~min}$ after initiation of hormonal treatment, so that comparisons during hormonal infusions were
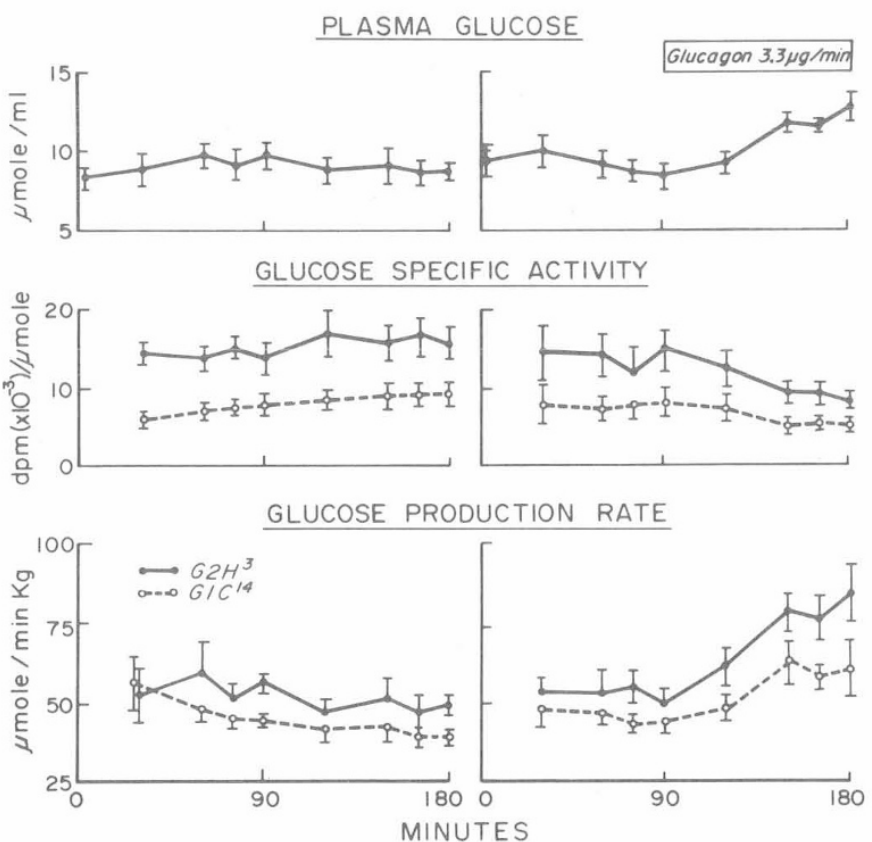

Fig. 1. Glucose metabolism in 14 newborn dogs, ages 1-5 days, during simultaneous infusions of $\left[2-{ }^{3} \mathrm{H}\right]$ glucose $(0.13 \mu \mathrm{Ci} / \mathrm{min})$ and $\left[1-{ }^{14} \mathrm{C}\right] \mathrm{glu}-$ cose $(0.064 \mu \mathrm{Ci} / \mathrm{min})$ after tracer priming. Results are expressed as mean \pm SEM 
Table 1. Glucose metabolism in newborn dogs

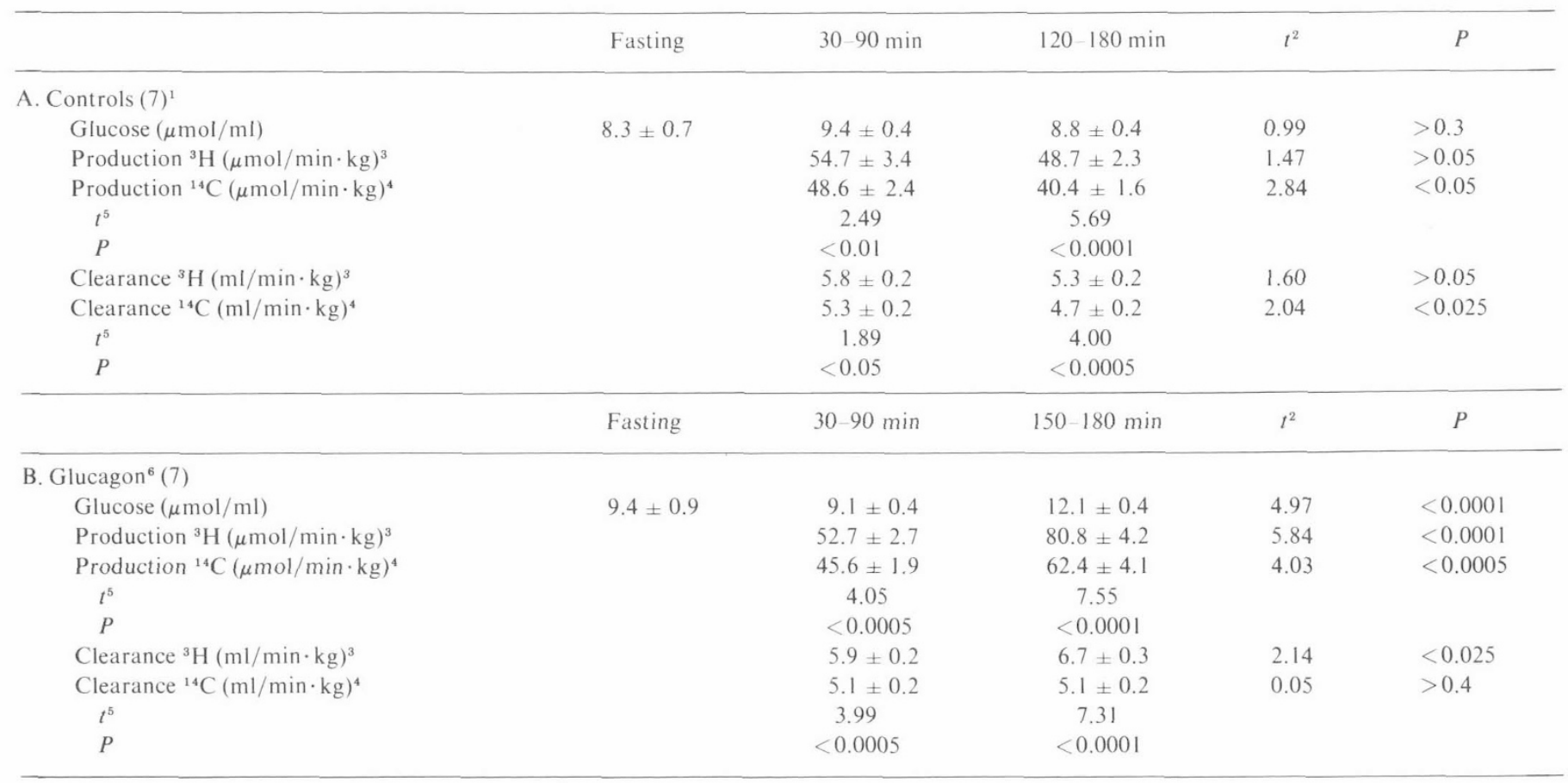

${ }^{1}$ Number of pups studied in each group.

${ }^{2}$ Student's $t$-test comparing pooled data from the control period between 30 and 90 min with the later study period assuming equal variance in the samples.

${ }^{3}$ Metabolic parameters estimated with $\left[2-{ }^{3} \mathrm{H}\right]$ glucose tracer.

${ }^{4}$ Metabolic parameters estimated with $\left[1-{ }^{14} \mathrm{C}\right]$ glucose tracer.

${ }^{5}$ Student's $t$-test of the mean difference between paired samples with $\left[2-{ }^{3} \mathrm{H}\right]$ glucose tracer and $\left[1-{ }^{14} \mathrm{C}\right]$ glucose tracer.

${ }^{6}$ Glucagon $(3.3 \mu \mathrm{g} / \mathrm{min})$ infused continuously between 90 and $180 \mathrm{~min}$.

restricted to samples obtained between 150 and $180 \mathrm{~min}$ of the tracer infusions. $P=I^{*} / W\left(G^{*} / G\right)$, where $P=$ systemic glucose production rate $($ micromoles per $\mathrm{min} \cdot \mathrm{kg}) ; \mathrm{I}^{*}=$ rate of infusion of isotopic tracer (disintegrations per $\min$ per $\mathrm{min}$ ); $\mathrm{W}=$ weight of newborn dog (kilograms); $G^{*} / G=$ specific activity of plasma glucose with respect to the tracer isotope infused (disintegrations per min per $\mu \mathrm{mol}$ ).

The quantity of glucose tracer infused was negligible compared with glucose production rates in all studies; therefore, there was no need to correct for the infused tracer by subtraction as would be required with chemical quantities of infused glucose.

Fractional $C_{1}$ Recycling (Fig. I, Table l). The amount of recycling of $C_{1}$ was inferred and quantified from the difference between glucose production rates determined with $\mathrm{G} 2{ }^{3} \mathrm{H}$ and $\mathrm{G} 1^{14} \mathrm{C} . \mathrm{R}=\mathrm{P}^{3} \mathrm{H}-\mathrm{P}^{14} \mathrm{C} / \mathrm{P}^{3} \mathrm{H}$, where $\mathrm{R}=$ the fraction of carbon recycled into $\mathrm{C}-1, \mathrm{P}^{3} \mathrm{H}=$ glucose production rate estimated from dilution of $\mathrm{G} 2{ }^{3} \mathrm{H}$ (micromoles per $\mathrm{min} \cdot \mathrm{kg}$ ), and $\mathrm{P}^{14} \mathrm{C}=$ glucose production rate estimated with $\mathrm{G} 1{ }^{14} \mathrm{C}$ (micromoles per min $\mathrm{kg}$ ). Recycling of glucose also was demonstrated directly by the incorporation of $\left[6-{ }^{14} \mathrm{C}\right]$ glucose into $\left[1-{ }^{14} \mathrm{C}\right]$ glucose as reported in Figure 2.

Fraction of Glucose Pool Derived from Lactate (Table 2). This was determined by the ratio of (total $\left[{ }^{14} \mathrm{C}\right]$ glucose specific activity) to $2\left(\left[{ }^{14} \mathrm{C}\right]\right.$ lactate specific activity). This result was confirmed by comparing $\mathrm{G}^{14} \mathrm{C}$ specific activity with that of $\mathrm{G} 6{ }^{3} \mathrm{H}$ as follows: $\mathrm{R}$ $=\mathrm{G}^{14} \mathrm{C}$ specific activity $/ \mathrm{G} 6{ }^{3} \mathrm{H}$ specific activity, where $\mathrm{R}=$ the fraction of the glucose pool derived from lactate. The specific activities were corrected appropriately for the assayed ratio of $\mathrm{L} 3{ }^{14} \mathrm{C}$ and $\mathrm{G} 6{ }^{3} \mathrm{H}$ in the infusate, and the calculation reported only after a steady state specific activity ratio of glucose to lactate was established (Table 2).

Metabolic Clearance Rate. Metabolic clearance rate (C) calculated in a steady state when glucose production rate $(\mathrm{P})$ equaled glucose uptake $(\mathrm{U}) . \mathrm{C}=\mathrm{U} / \mathrm{G}$ (milliliters per $\mathrm{min} \cdot \mathrm{kg})$, where $\mathrm{U}=$ glucose uptake (micromoles per $\mathrm{min} \cdot \mathrm{kg}$ ), $\mathrm{G}=$ plasma glucose concentration (micromoles per $\mathrm{ml}$ ).

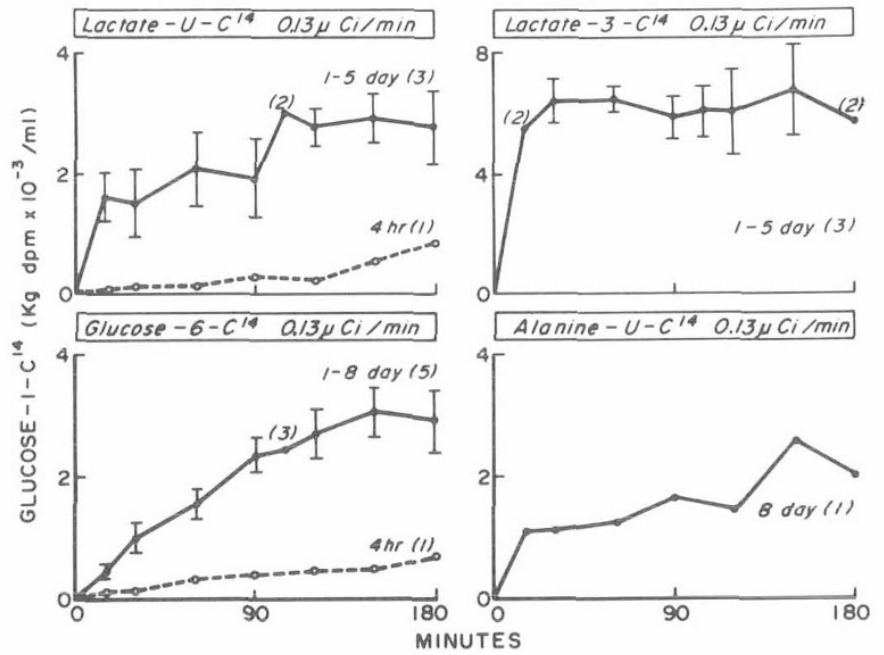

Fig. 2. Incorporation of ${ }^{14} \mathrm{C}$-substrates into $\left[1-{ }^{14} \mathrm{C}\right]$ glucose (mean \pm SEM). Number of pups in each group is indicated by the number in parentheses after the age range.

Differences between Production Rates Estimated with $G 2^{3} \mathrm{H}$ and $G I^{14} C$ tracers. These were compared with the paired Student's $t$ test. Pooled data in control and treated periods were compared in order to assess the change of glucose production rates with time and during glucagon infusion. All results are expressed as mean \pm SEM. Calculations were done with a Hewlett-Packard 9830 calculator system employing standard programs in BASIC.

\section{RESULTS}

HEPATIC GLUCOSE PRODUCTION (FIG. I, TABLE 1)

In 14 newborn dogs the mean plasma glucose stabilized during control periods in the range of $8-10 \mu \mathrm{mol} / \mathrm{ml}$. Infusion of glucagon 
Table 2. Fractional incorporation of $\left[3-{ }^{14} \mathrm{C}\right]$ lactate into $\left[1-{ }^{14} \mathrm{C}\right]$ glucose in one dog 5 days old
Tracer $^{1}$

$(n)^{2}$

Glucose $(\mu \mathrm{mol} / \mathrm{ml})$

$\mathrm{G}^{14} \mathrm{C} / 2 \mathrm{~L}^{14} \mathrm{C}^{3}$

$\mathrm{G}^{14} \mathrm{C} / \mathrm{G}^{3} \mathrm{H}^{4}$

$\mathrm{GIC}^{14} / \mathrm{GH}^{3}$
Lactate $(\mu \mathrm{mol} / \mathrm{ml})$ $\left[3-{ }^{14} \mathrm{C}\right]$ Lactate

(8)

$4.3 \pm 0.3$

$1.11 \pm 0.11$

$0.254 \pm 0.030$

$0.102 \pm 0.012$
$0.252 \pm 0.026$

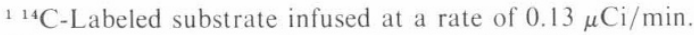

${ }^{2}$ Number of samples after steady state $\left[1-{ }^{14} \mathrm{C}\right]$ glucose specific activity (Fig. 2).

${ }^{3}$ Ratios determined from the relative specific activities. $\mathrm{G}^{14} \mathrm{C}$, $\left[{ }^{14} \mathrm{C}\right]$ glucose; $\mathrm{L}^{14} \mathrm{C},\left[{ }^{14} \mathrm{C}\right]$ lactate; $\mathrm{G}^{3} \mathrm{H},\left[{ }^{3} \mathrm{H}\right]$ glucose separated chromatographically. $\left[1-{ }^{14} \mathrm{C}\right]$ glucose $\left(\mathrm{G}^{14} \mathrm{C}\right)$ was determined enzymatically.

${ }^{4} \mathrm{G}^{3} \mathrm{H}$ derived from $\left[6-{ }^{3} \mathrm{H}\right]$ glucose infused simultaneously with $\mathrm{L} 3{ }^{14} \mathrm{C}$.

at $3.3 \mu \mathrm{g} / \mathrm{min}$ raised the plasma glucose concentration from $9.1 \pm$ $0.4 \mu \mathrm{mol} / \mathrm{ml}$ to a mean value of $12.1 \pm 0.4 \mu \mathrm{mol} / \mathrm{ml}$ between 150 and $180 \mathrm{~min}$ of the study.

In seven control dogs, both $\mathrm{G} 2{ }^{3} \mathrm{H}$ and $\mathrm{G} 1{ }^{14} \mathrm{C}$ specific activities were relatively stable from $30 \mathrm{~min}$ of study onward, but there was a gradual rise that was more marked with $\left[1-{ }^{14} \mathrm{C}\right]$ glucose. Glucagon treatment reduced the specific activity of both $\mathrm{G} 2{ }^{3} \mathrm{H}$ and $\mathrm{G} 1{ }^{14} \mathrm{C}$, an effect that was measurable from $120 \mathrm{~min}$ onwards. The specific activity of labeled glucose was relatively constant for both isotopes between 150 and 180 min of study.

Mean glucose production rates measured with tracer $\mathrm{G} 2^{3} \mathrm{H}$ stabilized at $53-55 \mu \mathrm{mol} / \mathrm{min} \cdot \mathrm{kg}$ in control periods and declined slightly to $49 \mu \mathrm{mol} / \mathrm{min} \cdot \mathrm{kg}$ between 120 and $180 \mathrm{~min}$ of study in the control dogs. Glucagon infusion raised systemic glucose production rates from $52.7 \pm 2.7 \mu \mathrm{mol} / \mathrm{kg} \cdot \mathrm{min}$ in the control period to $60.8 \pm 5.7$ at $120 \mathrm{~min}$ and $80.8 \pm 4.2 \mu \mathrm{mol} / \mathrm{kg} \cdot \mathrm{min}$ at $150-180 \mathrm{~min}$.

During the control periods, mean glucose production rates assessed with $\mathrm{G} 1{ }^{14} \mathrm{C}$ were $89 \%$ of those with $\mathrm{G} 2{ }^{3} \mathrm{H}$ tracer in control dogs, and $87 \%$ in those treated later with glucagon. This result implies that $11 \%$ to $13 \%$ of the C-1 in glucose was recycled to the same position. Although there was a slight decline in the proportion of glucose production estimated with $\mathrm{G} \mathrm{I}^{14} \mathrm{C}$ during the final $60 \mathrm{~min}$ of infusion in controls, glucagon infusion at pharmacological rates reduced the fractional estimate further to $77 \%$. This resulted in a reduction of the estimated hormonal effect on glucose production from a $53 \%$ increase with $\mathrm{G} 2{ }^{3} \mathrm{H}$ to $37 \%$ with $\mathrm{Gl}{ }^{14} \mathrm{C}$ tracer. Nevertheless, there was a significant increase of systemic glucose production rate from $45.6 \pm 1.9$ to $62.4 \pm 4.1 \mu \mathrm{mol} /$ $\mathrm{min} \cdot \mathrm{kg}$ when estimated with $\mathrm{G} 1{ }^{14} \mathrm{C}$.

\section{CONVERSION OF SUBSTRATE TO $\left[1-{ }^{14} \mathrm{C}\right]$ GLUCOSE (FIG. 2)}

Although glucagon infusion at the lower rate $(0.17 \mu \mathrm{g} / \mathrm{min})$ raised blood glucose on the third and fifth day of life, it had no effect on the incorporation of substrates into $\left[1-{ }^{14} \mathrm{C}\right]$ glucose. Similarly, insulin $(0.1 \mathrm{U} / \mathrm{kg})$ lowered blood glucose transiently but did not modify the plasma level of $\left[1-{ }^{14} \mathrm{C}\right]$ glucose compared with that in control animals. Thus, results from the incorporation studies have been grouped according to the ${ }^{14} \mathrm{C}$-labeled substrate infused.

In Figure 2, the conversion of ${ }^{14} \mathrm{C}$-labeled substrates to [1${ }^{14} \mathrm{C}$ ]glucose is displayed. Since there was a threefold variation in puppy size whereas each tracer was infused at a standardized rate, the results are normalized as indicated for puppy weight. This permitted gross comparisons of incorporation into $\left[{ }^{14} \mathrm{C}\right]$ glucose. All the substrates studied were incorporated into $\mathrm{G} /{ }^{14} \mathrm{C}$. When adjusted by weight, the plasma concentrations of $\left[1-{ }^{14} \mathrm{C}\right]$ glucose varied little and were indistinguishable for each substrate between 1 and 8 days of age. Only those obtained at $4 \mathrm{hr}$ were clearly different, and have been displayed separately.
In dogs between 1 and 8 days of age $\left[U-{ }^{14} \mathrm{C}\right]$ lactate, $\left[3-{ }^{14} \mathrm{C}\right]$ lactate, and $\left[U-{ }^{14} \mathrm{C}\right]$ alanine- $\mathrm{U}-\mathrm{C}^{14}$ infusions resulted in a marked rise of $\left[1-{ }^{14} \mathrm{C}\right]$ glucose within $15 \mathrm{~min}$ of the prime infusion, with a tendency to stabilize thereafter during the constant rate infusion of substrate. In contrast, $\left[6-{ }^{14} \mathrm{C}\right]$ glucose infused to five dogs between 1 and 8 days of age resulted in a continuous rise of plasma $\left[1-{ }^{14} \mathrm{C}\right]$ glucose during the first $90 \mathrm{~min}$. Between 90 and $180 \mathrm{~min}$ of infusion, $\left[1-{ }^{14} \mathrm{C}\right]$ glucose tended to stabilize at a relatively constant level.

As indicated, two newborn dogs at $4 \mathrm{hr}$ of age incorporated lactate into glucose or recycled glucose at much lower rates than at age 1-8 days (Fig. 2). During these infusions of $\mathrm{L} U^{14} \mathrm{C}$ at $4 \mathrm{hr}$ of age plasma $G 1{ }^{14} \mathrm{C}$ rose continuously at a very low rate throughout the infusions. and did not stabilize. Even at the end of the studies, plasma $\mathrm{G} 1{ }^{14} \mathrm{C}$ level was only $30 \%$ during $\mathrm{L} U^{14} \mathrm{C}$ infusion and $22 \%$ with $\mathrm{G} 6{ }^{14} \mathrm{C}$ of the mean levels obtained at later ages.

\section{QUANTIFICATION OF GLUCONEOGENESIS (TABLE 2)}

As quantified in Table 2, total plasma $\left[{ }^{14} \mathrm{C}\right]$ glucose specific activity was one-half of plasma $\left[{ }^{14} \mathrm{C}\right]$ lactate specific activity after a steady state was established, indicating that $25 \%$ of the glucose pool originated from $\mathrm{L} 3{ }^{14} \mathrm{C}$. The proportion of the glucose pool originating from ${ }^{14} \mathrm{C}$-labeled substrate also equaled $25 \%$ when $\left[{ }^{14} \mathrm{C}\right]$ glucose specific activity was compared with that of [6${ }^{3} \mathrm{H}$ ]glucose in plasma (Table 2).

\section{METABOLIC CLEARANCE RATES (TABLE 1)}

Metabolic clearance of glucose estimated with $\mathrm{G} 2{ }^{3} \mathrm{H}$ tracer in control periods varied between 5 and $6 \mathrm{ml} / \mathrm{min} \cdot \mathrm{kg}$ body weight. The metabolic clearance of $\mathrm{G} /{ }^{14} \mathrm{C}$ was always significantly less. Treatment with pharmacological quantities of glucagon (3.3 $\mu \mathrm{g} / \mathrm{min}$ ) raised $\mathrm{G} 2{ }^{3} \mathrm{H}$ clearance slightly by $17 \%$, while having no effect on the clearance of $\mathrm{G} 1{ }^{14} \mathrm{C}$.

\section{DISCUSSION}

\section{REGULATION OF GLUCOSE}

As indicated in the present study and others, systemic glucose production is established early in the newborn dog at rates which exceed those in the adult $(11,15)$. Presumably, most of the glucose is released by neonatal liver in response to events associated with birth such as hypoglycemia or hypoxia $(1,6,8,9)$. Based on measurements of plasma pancreatic hormones, glucose, and glucogenic substrate, various investigators have inferred that hepatic glucose production is initiated after birth by the rise of plasma glucagon occurring while plasma insulin stabilizes in the fasting range $(9,13)$. Furthermore, Varma et al. (15) have demonstrated that young dogs between $4.5 \mathrm{hr}$ and 55 days of age are less sensitive to insulin action in the physiological range than are adult dogs. During glucose infusions which raised plasma insulin to levels resembling those in the adult, these young dogs failed to suppress systemic glucose production completely or to increase the metabolic clearance of glucose effectively. In the present study the newborn dogs had low metabolic clearance rates for glucose, less than those observed previously in the young and adult dogs. These data imply that blood glucose was stabilized in the postabsorptive state by an underdeveloped or unstimulated insulin effect upon glucose uptake.

Stimulation with continuous glucagon infusion $(3.3 \mu \mathrm{g} / \mathrm{min})$ raised blood glucose approximately $3 \mu \mathrm{mol} / \mathrm{ml}$, in a manner resembling the response to a single glucagon pulse of $300 \mu \mathrm{g} / \mathrm{kg}$ between 24 and $96 \mathrm{hr}$ of age (3). Similarly, blood glucose stabilized between 60 and 120 min after the pulse or infusion, a fact which led previous investigators to suggest that hepatic glucose production was increased, although the uptake of glucose was not $(3,11)$.

In the present study, basal systemic glucose production in the postabsorptive state was the same as that observed in the isolated perfused canine liver $(4,5)$. In addition, the rise of glucose production stimulated by a pharmacological rate of glucagon 
infusion was the same as that observed in the isolated perfused canine liver stimulated with either glucagon or norepinephrine $10^{-6} \mathrm{M}(4,5)$. Thus the canine liver, at least potentially, could account for all the glucose produced in vivo. Furthermore, the metabolic clearance of glucose rose only $16 \%$ in the newborn dogs. Based on present evidence in the newborn mammal and infant, therefore, direct stimulation of the newborn liver by pancreatic glucagon or sympathetic neural norepinephrine $(5,7)$ raises hepatic production. Plasma insulin tends to remain in the fasting range unless combined stimulation with amino acids as well as glucose occurs (12). Finally, insulin is relatively ineffective in suppressing hepatic glucose production or elevating the metabolic clearance of glucose (15). Thus, the postnatal stabilization of blood glucose may reflect the unopposed action of pancreatic glucagon and sympathetic neural norepinephrine.

\section{SOURCES OF GLUCOSE}

As in other species, the canine fetus accumulates glycogen in the liver as term gestation approaches; the newborn dog has hepatic glycogen levels of approximately $500 \mu \mathrm{mol} / \mathrm{g}, 3$ times those in the postabsorptive adult (3). After birth, hepatic glycogen declines even in the fed newborn dog, stabilizing at low levels of 65-75 $\mu \mathrm{mol} / \mathrm{g}$ between 2 and 4 days of age $(3,4)$. Presumably this decline reflects the mobilization of hepatic glycogen to sustain blood glucose either while the newborn is fasting or as adequate caloric intake is being established.

Pharmacological doses of glucagon administered in vivo cause a decline of hepatic glycogen which correlates with the rise of blood glucose at ages earlier than $96 \mathrm{hr}$ (3); glucagon or norepinephrine in vitro cause a decline of hepatic glycogen which accounts for $80 \%$ of the glucose produced after 1 day $(4,5)$. Thus, it appears that hepatic glycogen accumulated in utero serves as a major source of systemic glucose production in the postabsorptive or hormonally stimulated state.

Nevertheless, the enzymatic activities required for gluconeogenesis from $\mathrm{C}-3$ intermediates are established within $3 \mathrm{hr}$ of birth (4) and measurable gluconeogenesis occurs from this time onwards. As would be expected, this has led to a discrepancy between methods for measuring hepatic glucose production. Estimates of systemic glucose production rate with uniformly labeled glucose are lower than those utilizing tritiated glucose as tracer $(10)$. In the present study, $\left[1-{ }^{14} \mathrm{C}\right]$ glucose and $\left[2-{ }^{3} \mathrm{H}\right]$ glucose tracers were utilized simultaneously to permit the evaluation of recycling. The assay of $\left[1-{ }^{14} \mathrm{C}\right]$ glucose quantified only $\mathrm{C}-1$ and estimated the ${ }^{14} \mathrm{C}$-label independently of tritiated glucose. Since $\mathrm{C}-1$ randomized away from its position during recycling and distributed in the carbon skeleton of glucose, a greater agreement was expected between estimates of glucose production utilizing $\mathrm{G} 1{ }^{14} \mathrm{C}$ and $\mathrm{G} 2{ }^{3} \mathrm{H}$ than would occur when uniformly labeled glucose was utilized. As indicated $\mathrm{G}{ }^{14} \mathrm{C}$ tracer infused at a constant rate gave an estimate of systemic glucose production in the newborn dog which was $11-13 \%$ below that with $\mathrm{G} 2{ }^{3} \mathrm{H}$ tracer. There was a moderate increase of recycling between 90 and $180 \mathrm{~min}$ of study, and a marked increase with the high doses of glucagon $(3.3 \mu \mathrm{g} / \mathrm{min})$

Direct measurement of gluconeogenesis and recycling in this study demonstrated that $\left[{ }^{14} \mathrm{C}\right]$ lactate was incorporated into glucose, and that $\left[6-{ }^{14} \mathrm{C}\right]$ glucose recycled as early as $4 \mathrm{hr}$ of age. Within the first day, functional gluconeogenesis and recycling of glucose in vivo had increased to a relatively constant level similar to that in the isolated perfused canine liver at 3-5 days of age.

Quantification of gluconeogenesis in a postabsorptive 5-day-old dog demonstrated that $25 \%$ of the glucose formed originated from lactate. The exactness of this estimate is affected by exchange of labeled carbon causing its loss from intermediate pools, plus the dilution of intermediate pools with other sources of unlabeled carbon. For example, a marked influx of unlabeled carbon from fatty acid metabolism during fasting would serve to dilute the specific activity and cycling would redistribute the labeled carbon of the intrahepatic oxaloacetate pool. Thus, the quantified estimate of gluconeogenesis represents a minimum value.
Nevertheless, these results resemble those in the isolated perfused liver with only ${ }^{14} \mathrm{C}$-labeled lactate as substrate in which lactate incorporation into glucose was established after birth, was $20 \%$ of functional $\mathrm{CO}_{2}$ fixation by intact mitochondria, and correlated directly with mitochondrial pyruvate carboxylase activity.

Finally, a comparison of plasma $\left[1-{ }^{14} \mathrm{C}\right]$ glucose in newborn dogs infused with $\left[3-{ }^{14} \mathrm{C}\right]$ lactate or $\left[6-{ }^{14} \mathrm{C}\right]$ glucose suggests that most of the gluconeogenesis in the first 5 days represents recycled glucose. In this context, recycling of glucose in the postabsorptive state may account for $25 \%$ or more of the hepatic glucose production. Thus, recycling apparently represents an important aspect of fuel economy and glucose homeostasis in the newborn dog.

\section{SUMMARY}

In the postabsorptive newborn dog hepatic glucose production is established shortly after birth; the potential for gluconeogenesis can be demonstrated within $4 \mathrm{hr}$ after spontaneous delivery. Most of the glucose produced originates from glycogen or unlabeled sources; but approximately $25 \%$ of it may originate from gluconeogenesis or recycling of glucose. The newborn canine liver is a target organ which responds to stimulation by pancreatic glucagon or sympathetic neural norepinephrine; however, hormonal stimulation of hepatic glucose production by the newborn dog may be relatively unopposed by pancreatic insulin.

\section{REFERENCES AND NOTES}

1. Adam, P. A. J.: Control of glucose metabolism in the human fetus and newborn infant. Advan. Metabol. Dis., 5: 183 (1971).

2. Adam, P. A, J., Räihä, N., Rahiala, E.-L., and Kekomäki, M.: Oxidation of glucose and D-B-OH-Butyrate by early human fetal brain. Acta Paediat. Scand., 64: 17 (1975).

3. Allen, D. T., Kornhauser, D., and Schwartz, R.: Glucose homeostasis in the newborn puppy. Amer, J. Dis. Child. 1/2:343 (1966).

4. Chlebowski, R., and Adam, P. A. J.: Glucose production in the newborn dog. II. Evaluation of autonomic and enzymatic control in the isolated perfused canine liver. 9: 000 (1975)

5. Chlebowski, R. Kalhan, S. C. Lowry, M. and Adam, P. A. J.: Autonomic and enzymatic control of glucose production in the isolated perfused canine fetal and neonatal liver [Abstract].Presented at the Society for Pediatric Research Meetings, San Francisco, May 1973. Pediat. Res., 7: 381 (1973).

6. Edwards, A. Y. and Silver, M.: The effect of asphyxia on the plasma glucose concentration in newborn calves. Biol. Neonat., /4: I (1969).

7. Edwards, A. Y., and Silver, M.: The glycogenolytic response to stimulation of the splanchnic nerves in adrenalectomized calves, J. Physiol. 211: 109 (1970).

8. Girard, J. R., Cuendet, G. S., Marliss, E. B., Kervran, A., Rieutort, M., and Assan, R.: Fuels, hormones and liver metabolism at term and during the early postnatal period in the rat. J. Clin. Invest., 52: 3190 (1973).

9. Goodner, G. J., Conway, M. J., and Werrbach, J. H.: Relation between plasma glucose levels of mother and fetus during maternal hyperglycemia, hypoglycemia and fasting in the rat. Pediat. Res., 3: 121 (1969).

10. Issekutz, B., Jr., Allen, M and Borkow, I.: Estimation of glucose turnover in the dog with glucose-2-T and glucose-U-C ${ }^{14}$. Amer. J. Physiol., 222: 710 (1972).

11. Kornhauser, D., Adam, P. A. J., and Schwartz, R.: Glucose production and utilization in the newborn puppy. Pediat. Res., 4: 120 (1970).

12. Reitano, G., Grasso, S., Distefano, G., and Messina, A.: The serum insulin and growth hormone response to arginine and to arginine with glucose in the premature infant. J. Clin. Endocrinol., 33: 924 (1971).

13. Sperling, M. A. DeLamater, P. V.. Phelps, D. Fiser, R. H., Oh, W., and Fisher. D. A.: Spontaneous and amino acid stimulated glucagon secretion in the immediate postnatal period. Relation to glucose and insulin. J. Clin. Invest. 53: 1159 (1974).

14. Stembera, Z. K., and Hodr, J.: II. Mutual relationships between the levels of glucose, pyruvic acid and lactic acid in the blood of the mother and of both umbilical vessels in hypoxic fetuses. Biol. Neonat., 10: 303 (1966).

15. Varma, S., Nickerson, H., Cowan, J. S., and Hetenyi, G., Jr.: Homeostatic responses to glucose loading in newborn and young dogs. Metabolism, 22: 1367 (1973).

16. New England Nuclear, Boston, Mass

17. Sigma Chemical Co., St. Louis, Mo.

18. Eli Lilly \& Co., Indianapolis, Ind.

19. This project was supported by Grant HD-05740 from the United States Public Health Service, National Institute of Child Health and Human Development.

20. Dr. Adam was supported by the National Institute of Arthritis and Metaboli Diseases Research Career Development Award 5-K04-AM-37485.

21. Requests for reprints should be addressed to: P. A. J. Adam, M.D., Departmen of Pediatrics, Cleveland Metropolitan General Hospital, 3395 Scranton Rd. Cleveland, Ohio 44109 (USA).

22. Accepted for publication July 3, 1975 